\title{
SALT ERROR IN DETERMINATIONS OF PHOSPHATE IN SEA WATER
}

\author{
By L. H. N. Cooper, D.Sc., F.I.C.
}

Assistant Chemist at the Plymouth Laboratory

Investigations extending over several years have shown that the salt error in colorimetric determinations of phosphate in sea water may be dependent, not only upon the concentrations of reagents and to some extent on the temperature, but also on the method of making the comparison. Uncertainty had become acute since alterations in procedure had been made, which were found to invalidate comparison between results obtained before and after 1933. Since we possess much the longest series of phosphate records yet made and these show promise of close correlation with other biological phenomena, it became essential to ensure that all were on a comparable basis.

\section{The Conditions of Formation of Phosphomolybdenum Blue}

From a detailed study Tischer (1934) concluded that:

(I) To reduce one molecule of phosphomolybdic acid to phosphomolybdenum blue four stannous ions are required.

(2) The experimental solution should lie between 0.09 and $0 \cdot \mathrm{I}_{7} \mathrm{~N} \mathrm{H}_{2} \mathrm{SO}_{4}$. This agrees with Kalle's finding (1934), since $100 \mathrm{ml}$. of water treated with I ml. of the usual acid molybdate reagent contains o. $\mathrm{I}_{4} \mathrm{~N} \mathrm{H}_{2} \mathrm{SO}_{4}$. The optimum normality of acid is very dependent on the amount of molybdate present (cf. Kalle, I934).

(3) The influence of $p \mathrm{H}$ is due to its effect on the competing oxidationreduction systems, phosphomolybdic acid $\rightleftharpoons$ phosphomolybdenum blue, $\mathrm{Sn}^{++++} \rightleftharpoons \mathrm{Sn}^{++}$and $\mathrm{H}^{+} \rightleftharpoons \mathrm{H}$. Electrometric measurements showed that the colour intensifying effect of sulphate is due to an increase in the $p \mathrm{H}$ of the reaction mixture.

(4) The depth of colour in distilled water, reached after thirty minutes, is independent of temperature but electrolytes give rise to a temperature coefficient.

(5) Chloride, in contrast to sulphate, causes not only a diminution but also an alteration in the shade of the reduced solution so complicating the salt error problem in work with sea water (cf. also Robinson \& Wirth, I935).

\section{Formation of Complex Molybdenyl Halides}

Reduction of molybdic acid in solution in strong hydrochloric or hydrobromic acid, either with hydrogen iodide or electrolytically at a platinized platinum electrode, leads to the formation of complex molybdenyl halides, 
$\mathrm{R}_{2}\left[\mathrm{MoOX}_{5}\right]$, where $\mathrm{R}$ is an alkali metal or an ammonium base and $\mathrm{X}$ is chlorine or bromine. Under suitable conditions these complexes may be crystallized, the chlorides being green and the bromides brown to yellow. They are all rapidly hydrolysed by water, the concentrated solutions being reddish brown passing through orange to bright yellow on dilution. The bromides are even more liable to hydrolysis than are the chlorides. The stages in the hydrolysis have been elucidated (James \& Wardlaw, I927; Angell, James \& Wardlaw, 1929). This work agrees with the views put forward by Tischer (1934). In a sample of sea water submitted to colorimetric analysis of phosphate we have all the conditions required for the formation of these complexeslarge amounts of chloride and some bromide, excess of molybdic acid, a degree of acidity sufficient to promote their formation and a reducing agent, present only in small quantity it is true, but more powerful than hydrogen iodide.

This formation of molybdenyl halides and their yellow hydrolytic products may be readily shown by adding a solution of stannous chloride, drop by drop, to a resting sample of sea water containing acid molybdate reagent. Bright yellow streaks will be seen slowly falling towards the bottom of the flask. Complete suppression of the complex molybdenyl halide formation is difficult, but it may be much reduced by rotating the solutions rapidly whilst the stannous chloride solution is being added, so avoiding a temporarily high local concentration of the reducing agent. It may also be reduced by cutting down the amount of stannous chloride added (Atkins, I928 p. 202). Controls are necessary to ensure that this is not cut down too much.

Between five and ten minutes after the addition, a slight development of yellow tint need not prevent an experienced analyst making a reproducible colour match. Since the yellow colour then develops more rapidly, comparison after half an hour or more is undesirable.

When colour filters are used a very serious source of error may arise. The formation of molybdenyl chlorides is accompanied by absorption not only in the blue and green but also in the red. This absorption in the red would be attributed to the presence of phosphate. In any one group of experiments where "yellowing" is taking place, it may be uniform and very difficult to detect by ordinary methods of control, using a photometer in a dimly lit room. When this happens the results may appear excellent; the colour increment for the addition of a given amount of phosphate may be uniform throughout a long series of determinations; blank measurements may appear in perfect order, and yet the content of phosphate found may be as much as $75 \%$ too high. The unsuitability of the solutions for analysis is at once evident when they are examined in bright daylight. The colour increment is also greater than is found when a good blue has developed. 


\section{StRENGth of Molybdate Reagent}

Kalle (I933, I934, I935 a, b) has made a detailed investigation of the optimum conditions for the analytical determination of phosphate in artificial sea water. He found (1934) that the usual molybdate reagent is blended in the right proportions, but that if the amount used were reduced by one-half the intensity of colour development was always increased and the salt error diminished. From Kalle's results with the Pulfrich photometer (S72 filter), using I ml. of molybdate reagent per $100 \mathrm{ml}$. of water, a correction factor, I. I3, was found, and agreed closely with determinations then made by the writer using Hehner cylinders and natural sea water-I.II and $I \cdot I 2$.

The reduced quantity of molybdate reagent ( $\mathrm{I}: \mathrm{I00}$ ) was adopted as standard practice in April 1934, but comparison in Hehner cylinders was continued in preference to the Pulfrich photometer.

\section{The EFFECT OF COPPER}

Subsequently Kalle (1935a) suggested that minute traces of copper affect the development of blue colour and are mainly responsible for the salt error. To overcome this he suggested adding copper to all standards and sea water samples, so that results would then not require correction for salt error. Tischer and Kalle agree that the depressing effect of increasing quantities of copper is represented by a curve with a flat inflection but do not agree as to its position. They both used I ml. of molybdate reagent per Ioo $\mathrm{ml}$. of water. The flat part of the curve, where increase in the amount of copper leads to no further decrease in colour, lies between 120 and $1200 \mathrm{mg} . / \mathrm{m}^{3}$ according to Kalle and between $\mathrm{I} 460$ and $8560 \mathrm{mg}$. $/ \mathrm{m} .{ }^{3}$ according to Tischer. With $250 \mathrm{mg} . / \mathrm{m} .{ }^{3}$, the decrease in colour in distilled water is about $3 \%$ according to Tischer, about $5 \%$ according to Kalle and about 10\% according to extensive experiments made by the writer. It is clear from Tischer's discussion that the effect of copper will be the greater the less the quantity of stannous chloride used.

As much copper as $30 \mathrm{mg} . / \mathrm{m} .{ }^{3}$ has been shown to have a negligible effect on colour development by Tischer, Kalle and the writer. With this the investigations of Robinson \& Wirth (1935) and Brambel \& Cowles (I937) agree. Such an amount of copper has never been found in our distilled water nor in our sea-water samples, so that we feel that no phosphate analyses here are likely to be affected in this way. Since our Nansen-Pettersson sampling bottle is made of a copper alloy which has corroded badly, a number of tests have been made for contamination of the samples by copper. During the few minutes of a routine haul from less than $100 \mathrm{~m}$. contamination is not serious, but when water had been left in the sampling bottle for four hours during the journey back to the laboratory it was found to have been enriched with $500 \mathrm{mg} . / \mathrm{m}{ }^{3}$ Thus in working at greater depths or with less attention to 
washing the bottle with fresh water after the day's work, there is an ever present risk of serious contamination. The alloy used in the hydrographical bottles is unsatisfactory and an effort should be made to build them of incorrodible components such as stainless steel and ebonite, or silver-lined bottles of the Discovery Expedition type should be used.

From June 1936 to October 1937 copper was added to all our standards and sea-water samples prior to analysis $(25 \mu \mathrm{g}$. Cu and I ml. of molybdate reagent per $100 \mathrm{ml}$.). The development of colour was diminished but to the same extent in both sea water and standards (Tables I and II). The phosphate results required the same correction factor as though no copper had been added.

\section{DETERMINATION OF SALT ERROR}

The method of phosphate analysis is that of Denigès as applied to sea water by Atkins (1923). The reagent blank, which includes colour due to impurities in the reagents, natural colour of the water and any colour due to slight reduction of molybdic acid in absence of phosphate, was evaluated as described by Cooper (1933, p. 715).

\section{Table I. Effect of Copper on Salt Error Correction Factor.}

\begin{tabular}{|c|c|c|c|c|c|}
\hline & & $\begin{array}{r}\text { Comparison } \\
\text { light in } \mathrm{H} \\
\text { cylind }\end{array}$ & $\begin{array}{l}\text { by day- } \\
\text { ehner } \\
\text { ers }\end{array}$ & $\begin{array}{l}\text { Comparison } \\
\text { filter in } \mathrm{P} \\
\text { photon }\end{array}$ & $\begin{array}{l}\text { with S7 } \\
\text { lfrich } \\
\text { leter }\end{array}$ \\
\hline (D.W. $=$ dis & $\begin{array}{l}\text { rs compared } \\
\text { water; S.W. = sea water) }\end{array}$ & $\begin{array}{c}\text { No. of } \\
\text { Determina- } \\
\text { tions }\end{array}$ & $\begin{array}{l}\text { Mean } \\
\text { Factor }\end{array}$ & $\begin{array}{c}\text { No. of } \\
\text { Determina- } \\
\text { tions }\end{array}$ & $\begin{array}{l}\text { Mean } \\
\text { Factor }\end{array}$ \\
\hline & & $2 \mathrm{ml} .1$ & nolybdate & e reagent/roo & $\mathrm{ml}$. \\
\hline dded $\mathrm{Cu}$ & D.W. +4 mg.-atom $/ \mathrm{m}^{3}$ added $\mathrm{Cu}$ & - & - & 2 & $\mathrm{I} \cdot \mathrm{I} 5$ \\
\hline led Cu & S.W. + no added Cu & 2 & $I \cdot 36$ & 2 & $\mathrm{I} \cdot 23$ \\
\hline ided Cu & S.W. $+4 \mathrm{mg} .-$ atom $/ \mathrm{m}^{3}$ added $\mathrm{Cu}$ & 二 & - & I & $\mathrm{I} \cdot 25$ \\
\hline g.-atom $/ \mathrm{m} .^{3}$ & S.W. +4 mg.-atom $/ \mathrm{m}^{3}$ added $\mathrm{Cu}$ & I & $I \cdot 25(?)$ & 2 & $I \cdot 13$ \\
\hline & & I $\mathrm{ml}$ & nolybdate & e reagent/Ioc & $\mathrm{ml}$. \\
\hline ded $\mathrm{Cu}$ & D.W. +4 mg.-atom $/ \mathrm{m}^{3}$ added $\mathrm{Cu}$ & - & - & 9 & $I \cdot I I$ \\
\hline led $\mathrm{Cu}$ & S.W. + no added $\mathrm{Cu}$ & 3 & $I \cdot I I$ & 5 & $\mathrm{I} \cdot 07$ \\
\hline dded $\mathrm{Cu}$ & S.W. $+4 \mathrm{mg}$--atom $/ \mathrm{m}^{3}$ added $\mathrm{Cu}$ & - & - & 4 & $\mathrm{I} \cdot 23$ \\
\hline g.-atom $/ \mathrm{m}^{3}$ & S.W. $+4 \mathrm{mg}$. -atom $/ \mathrm{m}^{3}$ added $\mathrm{Cu}$ & 2 & $\mathrm{I} \cdot \mathrm{IO}$ & 8 & $\mathrm{I} \cdot \mathrm{IO}$ \\
\hline
\end{tabular}

In certain experiments the amount of acid molybdate was reduced from 2 to I ml. per Ioo ml. of water (cf. Kalle I935b; Tischer 1934). No attempt was made exactly to control temperature. In winter during the day the laboratory temperature ranged from II to $15^{\circ} \mathrm{C}$. During the experiments of June 1936 it was $17^{\circ} \mathrm{C}$. The acid ammonium molybdate reagent was prepared as described by Atkins (1923). The solution of stannous chloride was freshly made by dissolving $0 \cdot 10-0 \cdot 15 \mathrm{~g}$. $\mathrm{SnCl}_{2} \cdot 2 \mathrm{H}_{2} \mathrm{O}$ in $25 \mathrm{ml}$. $4 \mathrm{~N}$ hydrochloric acid. A solution made by dissolving metallic tin in hydrochloric acid in presence of a little copper sulphate (Atkins 1923) is equally effective. 
One drop of the stannous chloride solution added to $\mathrm{IoO} \mathrm{ml}$. of water containing $0.5 \mathrm{mg}$.-atom $/ \mathrm{m} .{ }^{3} \mathrm{P}$ ( $15 \mathrm{mg} . / \mathrm{m} .{ }^{3} \mathrm{P}$ ) gives a sixfold excess of stannous ions. Stronger solutions of phosphate require more stannous chloride but the same amount must be added to standards as well. If there should be any doubt as to whether sufficient stannous chloride has been added, the increment of colour due to, say, $0.3 \mathrm{mg}$.-atom $/ \mathrm{m}^{3} \mathrm{P}$ should be determined.

Direct visual comparison was usually made in Hehner cylinders $20 \mathrm{~cm}$. high. In work with the Pulfrich photometer, absorption tubes $15 \mathrm{~cm}$. long and holding about $90 \mathrm{ml}$. of liquid were used in conjunction with the red $\mathrm{S}_{72}$ filter. This shows maximum absorption above $700 \mathrm{~m} \mu$. (see Cooper and Milne, I938, Fig. I).

\section{Table II. Salt Error Correction Factor for Phosphate in Sea Water} UNDER DifFerent CONDITIONS OF DETERMINATION

$\overbrace{\text { Date }}^{\begin{array}{c}\text { Comparison by daylight } \\ \text { in Hehner cylinders }\end{array}} \underbrace{}_{\text {Factor }}$

Comparison in Pulfrich photometer with $\mathrm{S}_{72}$ filter

$\overbrace{\text { Date Factor }}$

I. Using I ml. of molybdate reagent per $100 \mathrm{ml}$. of water.

(a) No copper added to either sea water or standard.

\begin{tabular}{|c|c|c|c|}
\hline June $1934 a$ & I. II & Jan. I936a & 1.05 \\
\hline June $1934 b$ & $I \cdot I 2$ & Jan. I $936 b$ & 1.09 \\
\hline March 1936 & I.09 & June 1936 & $I \cdot 13$ \\
\hline Jan. $193^{8}$ & $I \cdot I 5$ & Sept. I936 & $(\mathrm{I} \cdot 00 ?)$ \\
\hline Feb. I938 & $\mathrm{I} \cdot \mathrm{I} 7$ & $\begin{array}{l}\text { Jan. I937 } \\
\text { Jan. I938 }\end{array}$ & $\begin{array}{l}I \cdot I 3 \\
I \cdot I I^{\star}\end{array}$ \\
\hline Mean & $I \cdot 13$ & & $\overline{I \cdot I I}$ \\
\hline
\end{tabular}

(b) $0.4 \mathrm{ml} . \mathrm{M} /$ Ioo० $\mathrm{CuSO}_{4}$ added to sea water and standards.

\begin{tabular}{llll} 
March I936 & $\mathrm{I} \cdot 09$ & Jan. I936 & $\mathrm{I} \cdot \mathrm{I} 3$ \\
Dec. I937 & $\mathrm{I} \cdot \mathrm{IO}$ & Sept. I936 & $\mathrm{I} \cdot 04$ \\
& & Jan. I937 & $\mathrm{I} \cdot \mathrm{IO}$ \\
Mean & & Dec. I937 & $\underline{I} \cdot \mathrm{IO}$ \\
\cline { 2 - 3 } & $\underline{\mathrm{I} \cdot \mathrm{IO}}$ & & $\underline{\mathrm{I} \cdot \mathrm{IO}}$ \\
\hline
\end{tabular}

II. Using $2 \mathrm{ml}$. of molybdate reagent per $100 \mathrm{ml}$. of water.

No copper added to either sea water or standard.

\begin{tabular}{llll} 
March 1936 & $\mathrm{I} \cdot 37$ & June I936 & $\mathrm{I} \cdot 23$ \\
Feb. I938 & $\mathrm{I} \cdot 35$ & Jan. I937 & $\underline{\mathrm{I} \cdot \mathbf{2 2}}$ \\
Mean & $\underline{\mathrm{I} \cdot 36}$ & & $\underline{\mathrm{I} \cdot 22}$ \\
\hline
\end{tabular}

* Result of an experiment with extensive cross-checks and controls; has been given the weight of four experiments.

In Tables I and II are collected determinations of the correction factor for salt error in sea water under different experimental conditions; in Table III may be found those by other workers.

When I ml. of molybdate reagent is used per $100 \mathrm{ml}$. of water the method of comparison is immaterial. The correction factor, $\mathrm{I} \cdot \mathrm{I} 2$, has been adopted for all the writer's determinations with I $\mathrm{ml}$. molybdate per $100 \mathrm{ml}$. of water, no matter whether comparison had been made by direct comparison of 
the blue colour in Hehner cylinders or by means of the red $\mathrm{S}_{72}$ filter in the Pulfrich photometer, or whether or not extra copper had been added to both sea water and standards.

However, when double the concentration of reagent is used ( $2: 100$, as in Atkins' original method), the correction factor is considerably greater for comparison by daylight $(\mathrm{I} \cdot 35)$ than when a red filter is used in some kind of photometer (I.I9). It is evident that the spectral composition of the blue

Table III. Correction Factor for Salt Error for Sea Water of $35 \%$ SALINITY

\section{Method Author}

(a) When $2 \mathrm{ml}$. of acid molybdate reagent is used per $100 \mathrm{ml}$. of sea water.

Spectrophotometer with filters having maxima at 660 and $684 \mathrm{~m} \mu$

Photoelectric colorimeter; $650 \mathrm{~m} \mu$

Pulfrich Photometer and S72 filter

$$
\text { " } "
$$

filters

Mean of measurements with filters

Comparison by daylight

$\begin{array}{lll}y & y & , \\ y & y & y \\ y & y & y\end{array}$

(b) When I ml. of acid molybdate reagent is used per $100 \mathrm{ml}$. of sea water.

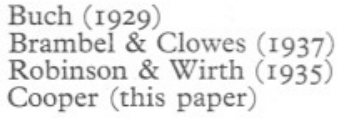

Ibañez

Brujewicz \& Krasnowa (1933)

Redfield, Smith \& Ketchum (I937)

Cooper (this paper)

Igelsrud, Robinson \& Thompson (1936)

Factor (a)

Pulfrich photometer and $\mathrm{S}_{72}$ filter

,,$\quad$,

Kalle (I934)

Cooper (this paper)

Mean of measurements with filters

Comparison by daylight

Cooper (this paper)

* Buch found that the salt error varied with the concentration of phosphate. The figure given is taken from his Tables and graphs for amounts of phosphate up to about I mg.-atom/ $\mathrm{m} \cdot{ }^{3} \mathrm{P}$.

+ From graph.

For waters containing less than I. I mg.-atom $/ \mathrm{m} \cdot{ }^{3} \mathrm{P}$.

For water of $29 \%$ salinity.

colour differs somewhat according to the amount of reagent used. The factor I. 35 has been adopted for correcting all direct visual determinations made by Atkins and the writer, using $2 \mathrm{ml}$. of molybdate reagent per $100 \mathrm{ml}$. of water.

Small variations in these factors arise from variations in the concentration of stannous chloride and in temperature. The correction factor must not be assumed to be a true constant. It is desirable therefore that each worker should establish the factor afresh for the precise conditions applying to his own work.

There is some evidence (Table I) that, when $2 \mathrm{ml}$. of molybdate reagent is used per $100 \mathrm{ml}$. the presence of copper $\left(c a .200 \mathrm{mg} . / \mathrm{m}^{3}\right)$ affects differentially the development of colour in distilled water standards and in sea water. In presence of copper the salt error factor for comparison by daylight may be about $I \cdot 25$, but this figure is the result of one determination only. 
Analyses here are now carried out by the procedure described by Wattenberg (I937), except that only 0.05 or 0.I0 g. of stannous chloride dissolved in $25 \mathrm{ml} .4 \mathrm{~N}$ hydrochloric acid is used since hydrolysis is thereby more completely suppressed. They are invariably made within 24 hours of collection.

\section{SUMMARY}

The yellowing which may occur during phosphate determinations in sea water is attributed to hydrolytic products of complex molybdenum halides.

When I ml. of the usual acid molybdate reagent is used per $100 \mathrm{ml}$. of water, addition of copper as recommended by Kalle reduces the development of colour in sea water samples and in distilled water standards to the same extent. The correction factor $\mathrm{I} \cdot \mathrm{I} 2$ applies to comparison by daylight in Hehner cylinders and to photometric determinations with a red filter.

When $2 \mathrm{ml}$. of reagent is used per $100 \mathrm{ml}$. of water, the factor depends on the method of comparison. With comparison by daylight in Hehner cylinders it is $I \cdot 35$, whereas if a photometer with a red filter is used it is only I.I9.

\section{REFERENCES}

Angell, F. G., James, R. G. \& Wardlaw, W., I929. Complex bromides of quinquevalent molybdenum. Fourn. Chem. Soc., pp. 2578-89.

AtKINS, W. R. G., I923. The phosphate content of fresh and salt waters in its relationship to the growth of the algal plankton. Fourn. Mar. Biol. Assoc., Vol. xirI, pp. II9-50.

- 1928. Seasonal variations in the phosphate and silicate content of sea water during 1926 and 1927 in relation to the phytoplankton crop. Fourn. Mar. Biol. Assoc., Vol. xv, pp. I9I-205.

BRAMBEL, C. E. \& Cowles, R. P., I937. The photoelectric determination of phosphorus in estuarine waters. Science, Vol. 85, pp. 340-2.

Brujewicz, S. W. \& Krasnowa, W. S., I933. Cited by S. W. Brujewicz in Methods of Chemical Oceanography (in Russian), Moscow, I933, p. II8.

$\mathrm{BuCH}, \mathrm{K}$., I929. Úber die Bestimmungen von Stickstoffverbindungen und Phosphaten im Meerwasser. Rapp. Proc.-Verb. Cons. Int. Expl. Mer, Vol. LIII, pp. 36-52.

Cooper, L. H. N., I933. Chemical constituents of biological importance in the English Channel. Pt. I. Fourn. Mar. Biol. Assoc., Vol. xvin, pp. 677-728.

Cooper, L. H. N. \& Milne, A., I938. The ecology of the Tamar Estuary. II. Underwater illumination. Fourn. Mar. Biol. Assoc., Vol. xxII, pp. 509-27.

IBAÑEZ, O. G., I933. Note on the effect of salts in the determination of phosphate in sea water by Denigès' method. Fourn. Cons. Int. Expl. Mer, Vol. viII, pp. 326-9.

[GelsRud, I., Robinson, R. J. \& ThOMPson, T. G., I936. The distribution of phosphate in the sea water of the north-east Pacific. Univ. Washington Publ. Oceanogr., Vol. 3, No. I, pp. I-34.

JAMES, R. G. \& WARDLAW, W., I927. Co-ordination compounds of quinquevalent molybdenum. Fourn. Chem. Soc., pp. 2145-56.

KALLE, K., I933, I934, I935a, b. Meereskundliche chemische Untersuchungen mit Hilfe des Zeisschen Pulfrich-Photometers. II. Arbeitsweise. III. Methodische Untersuchung der Phosphatgehaltsbestimmung. IV. Der Einfluss chemischer Stoffe auf die Phosphatgehaltsbestimmung. V. Die Bestimmung des GesamtPhosphorgehaltes, des Plankton-Phosphorgehaltes (lebende Substanz) und Trübungsmessungen. Ann. d. Hydrogr., Jahrg. LXI, pp. I24-8; LXII, pp. 65-74 and 95-102; LXIII, pp. 58-65, 195-204. 
Redfield, A. C., Smith, H. P. \& Ketchum, B., I937. The cycle of phosphorus in the Gulf of Maine. Biol. Bull., Vol. LxxiII, pp. 42I-43.

RobINSON, R. J. \& WIRTH, H. E., I935. Photometric investigation of the ceruleomolybdate determination of phosphate in waters. Ind. Eng. Chem. (Anal.), Vol. 7, pp. 147-56.

TIscher, J., I934. Ưber die Bestimmung des Phosphorsäure mittels der PhosphorMolybdänblau-Methode und deren Anwendung auf Pflanzenaschen. Zeits. Pflanzenernährung Düngung $u$. Bodenkunde, Teil A, Bd. 33, pp. 192-242.

WATTENBERG, H., I937. Critical review of the methods used for determining nutrient salts and related constituents in salt water. Rapp. Proc.-Verb. Cons. Int. Expl. Mer, Vol. cIII, pp. I-26.

\section{APPENDIX}

On 13 April 1938, after this paper had been prepared, a fresh batch of acid molybdate reagent was made up. Using I $\mathrm{ml}$. of this per $100 \mathrm{ml}$. of water, the salt error correction factor was found to be I.39 instead of I.I2 as anticipated. Moreover the factor decreased with time:

$\begin{array}{ll}\text { April I4 } & \mathrm{I} \cdot 39 \\ \text { April I9 } & \mathrm{I} \cdot 33 \\ \text { May I3 } & \mathrm{I} \cdot 29 \\ \text { June } 8 & \mathrm{I} \cdot 29 \\ \text { July 24 } & \mathrm{I} \cdot 25\end{array}$

To remove a slight yellow tint, the $50 \%$ (by volume) sulphuric acid had been treated with a few drops of $\mathrm{N} /$ Io permanganate as suggested by Kalle (I934) (0.4 mg. Mn per litre of acid molybdate reagent). The resulting manganous salt, although very small, provided a possible explanation of the anomalous correction factor. To test this view, two fresh $400 \mathrm{ml}$. batches of acid molybdate reagent were prepared on July 28, one treated with permanganate as above, the other not. The same samples of ammonium molybdate and sulphuric acid were used as in April. The salt error correction factor, determined by direct visual comparison in Hehner cylinders, was, in each case, I.II, in agreement with the value established on p. 176. The anomalous factor cannot therefore be attributed to the presence of manganese. Further search for the cause of the anomaly has not been made but, nevertheless, this experience emphasizes the need for care if accurate results are to be had. 